University of Wollongong

Research Online

Faculty of Social Sciences - Papers (Archive) Faculty of Arts, Social Sciences \& Humanities

2014

Learning wisdom through collectivity: The Women Writing Women

Collective

Luanne Armstrong

Barbara Bickel

Lynn Fels

Gillian Gerhard

Alyson Hoy

See next page for additional authors

Follow this and additional works at: https://ro.uow.edu.au/sspapers

Part of the Education Commons, and the Social and Behavioral Sciences Commons

Research Online is the open access institutional repository for the University of Wollongong. For further information contact the UOW Library: research-pubs@uow.edu.au 


\title{
Learning wisdom through collectivity: The Women Writing Women Collective
}

\author{
Abstract \\ The Women Writing Women Collective was a collegial and collaborative response to the isolation that is \\ often experienced by women scholars as they pursue their academic careers. For 5 years, a group of \\ women gathered on a monthly basis to share their writing. In doing so, the group members provided a \\ sounding board for each other as they engaged with writing and scholarship through reflective, reciprocal, \\ and responsible critique and curiosity. As a writing collective, we began to recognize and deconstruct \\ specific institutional constraints, practices, and theoretical stances that had influenced our perspectives \\ and experiences of what it means to be women writing in the academy. Within this process of critical \\ reflective practice, our scholarship, our writing, and our sense of community was strengthened. Within \\ this article, we share our experiences of women writing and learning together

\section{Keywords} \\ learning, women, collectivity, collective, wisdom, writing \\ Disciplines \\ Education | Social and Behavioral Sciences \\ Publication Details \\ Armstrong, L., Bickel, B., Fels, L., Gerhard, G., Hoy, A., Jordan, N., Nielsen, W. S., Smith, A., Stubbs, J. \& \\ Triggs, V. (2014). Learning wisdom through collectivity: The Women Writing Women Collective. NASPA \\ Journal About Women in Higher Education, 7 (1), 1-18.

\section{Authors} \\ Luanne Armstrong, Barbara Bickel, Lynn Fels, Gillian Gerhard, Alyson Hoy, Nane Jordan, Wendy S. Nielsen, \\ Annie Smith, Jeannie Stubbs, and Valerie Triggs
}




\section{Learning Wisdom Through Collectivity: The Women Writing Women Collective}

\author{
Luanne Armstrong \\ Adjunct Professor of Creative Writing \\ The University of British Columbia \\ Barbara Bickel \\ Associate Professor of Art Education \\ Director of Women, Gender and \\ Sexuality Studies \\ Southern Illinois University, Carbondale \\ Lynn Fels \\ Associate Professor of Arts Education \\ Simon Fraser University \\ Gillian Gerhard \\ Faculty of Science Liaison - Center for \\ Teaching, Learning \& Technology \\ Strategist, Learning \& Teaching Initiatives \\ The University of British Columbia \\ Alyson Hoy \\ Government of Canada Employee
}

\author{
Nané Jordan \\ Independent Artist/Scholar \\ Vancouver, British Columbia, Canada \\ Wendy Nielsen \\ Senior Lecturer in Science Education \\ University of Wollongong \\ Annie Smith \\ Professor of Drama \\ Grande Prairie Regional College \\ Jeannie Stubbs \\ Secondary English Teacher \\ Sands Secondary School, Delta \\ School District \\ Valerie Triggs \\ Assistant Professor of Art Education \\ University of Regina
}

Correspondence concerning this article should be addressed to Barbara Bickel, bickel.barbara@gmail.com.

The Women Writing Women Collective at the time of this paper writing was composed of the following members: Luanne Armstrong, Barbara Bickel, Lynn Fels, Gillian Gerhard, Alyson Hoy, Nané Jordan, Wendy Nielsen, Annie Smith, Jeannie Stubbs, and Valerie Triggs. Authorship and ownership is shared equally among all authors.

The Collective has dispersed since its last gathering in 2009. The women are now located in six different cities, three countries, and two continents. The threads of the relationships they cocreated entwine and reverberate in a variety of ways as they each continue their writing as teachers and artists in and outside of the academy.

NJAWHE 2014, 7(1)

(c) NASPA 2014

http://journals.naspa.org/njawhe

doi:10.1515/njawhe-2014-0002 
The Women Writing Women Collective was a collegial and collaborative response to the isolation that is often experienced by women scholars as they pursue their academic careers. For 5 years, a group of women gathered on a monthly basis to share their writing. In doing so, the group members provided a sounding board for each other as they engaged with writing and scholarship through reflective, reciprocal, and responsible critique and curiosity.

As a writing collective, we began to recognize and deconstruct specific institutional constraints, practices, and theoretical stances that had influenced ourperspectives and experiences of what it means to be women writing in the academy. Within this process of critical reflective practice, our scholarship, our writing, and our sense of community was strengthened. Within this article, weshare our experiences of women writing and learning together.

\section{The Collective}

Our conversations, our collaborations, our writing, and our theorizing together provide us with radical revision of community, academic or otherwise. Our collaborations open us up to a feminist imagination that moves us beyond the "ism." This is an imagination that explores the nature and value of our relationships to each other, of taking risks. This imagination demands courage. (Dunlop, 2002, p. 12)

The Women Writing Women Collective was created on a sunny afternoon under an apple tree by women scholars seeking a venue and practice that would support and encourage their engagement with scholarly writing. We were a diverse group of writers, graduate students, educators, artists, and academics who came from backgrounds in curriculum, drama, engineering, English, art, science, women studies, creative writing, elementary, secondary, higher and adult education. These various areas of experience and multiple perspectives framed our explorations of coming together to listen and share our writing. Our engagement made visible the multiple ways of being and knowing within our individual and shared fields of interest, and highlighted many of the challenges that we were experiencing in the journey of our career development.

The Women Writing Women Collective offered its members an opportunity to share writing and theoretical challenges, to listen to and engage in new and emergent forms of scholarly writing, and to write collectively. We met once a month at each other's homes on a rotational basis. Membership 
varied from seven to ten members over the 5-year period, with a few of us being involved since the collective's inception. Invitations to new members were discussed with the whole group before being extended to others.

The Collective provided a sounding board, and let us explore new ways of scholarly engagement through a reflective, reciprocal, responsible writing practice. Our meetings enabled an honest response to the isolation that is often experienced by female academics engaged in (un)conventional scholarship (Asmar, 1999). We actively brainstormed individual and collaborative writing projects, shared theorists and texts, and assisted each other in developing the theoretical underpinnings of our work. Together we came to recognize and deconstruct some of the institutional constraints, practices, and theoretical stances that had influenced our perspectives and experiences of what it means to be women writing in the academy.

At this point of our journey, we turn around and recognize the learning that has emerged from our participation in the Women Writing Women Collective. We share the key themes and some critical moments of our experience, and examine why our collective engagement mattered to us (and to the renewal of the academic community), as we learned to work together and support each other's scholarship. This particular article is a cocreation initiated by a number of us who gathered together at the home of one of the Collective's cofounders. We continued online with other members with whom we shared personal stories, performed writing, and engaged in dialogue about the evolution of our collective. In assembling the finished product, we chose to incorporate moments of exchange and writings that best spoke to our experience and insights, and which were critical to the group's evolution as a scholarly community of practice (Wenger, 1998). The article reflects our desire to deconstruct conventional academic practices and to create a meaningful narrative borne out of our experience as a writing collective.

\section{Seeking Collegiality and Reciprocity}

Our purpose in the Women Writing Women Collective was to explore scholarly writing that evoked desire, longing, fear, reverence, irreverence, reciprocity, joy, and awe. We wondered whether scholarly writing could evoke the as-yet unknown, rather than merely represent that which is already known. We invited new inquiries and encountered unanticipated spaces. Our Collective was deeply personal, yet also allowed for public explorations into meaning making. By reflecting upon and revealing the layers of our collectivity through conference presentations, we shared the benefits and values of responsibility to

NJAWHE 2014, 7(1)

(C) NASPA 2014

http://journals.naspa.org/njawhe

Authenticated | 129,128,70.74

Download Date | 4/7/14 7:16 PM 
others and the capacity that collectivity enables for adaptive growth, evolving resilience, and action in the world.

Ironically, while we were learning to value collaborative writing as a generative space, we met within a society and academic culture that celebrates individualism and competition (Reynolds, 1992). As we wrote through a variety of projects, our conversations inevitably led us to a few questions: How do we begin to shift a hierarchical academic model of individual competition to one that recognizes and values collaborative scholarly engagement and authorship? How do we, as educators, and women in the academy, transfer our knowledge and experience of working collaboratively to that institution so that academic life is not an isolating experience, but one of well-being, support, and mutual commitment to each other's professional success? As our experience suggested, it was through critical and interpersonal reflection that included care and respect that we began to reimagine how we might engage with others in the academy in a supportive and meaningful way.

I've never had the right words to describe my life, and now that I've entered my story, I need them more than ever. (Eugenides, 2002)

There is a real sense of urgency in the words spoken by the narrator of Eugenides' novel that reflects the difficulty and, at times, despair entailed by the intimate and solitary work of writing. Part of the value of our group was an exchange of words and ideas that helped each of us, in turn, to locate the key thoughts and language for our work. And yet, such a collective endeavor seems counterintuitive, given the loneliness inherent, and perhaps even necessary in the writing process. Where else but in spaces of quiet solitude is it possible to enter into a writing life, and so, begin to articulate the barely audible but deeply felt experiences that we seek to address?

As a feeling and a space that allows for exploration of the curious and often ambiguous relations between alienation and solitude, loneliness is, for some, the central and defining experience of a writer's life. And yet, importantly, loneliness also signifies "a relation necessary for thinking and for crafting a kind of freedom within one's inner world” (Britzman, 2003, p. 151). So much of a writer's ability to "make a life from words" (Britzman, 2006, p. xiii) depends upon the ability of the author to engage in a reflective turning inward of the self and, thus, encounter one's own otherness.

As estranging as it sometimes is, loneliness is also an experience that allowed each of us to reach out to each other and, thus, to the world. The Women Writing Women Collective signified a space of reaching out and of encoun- 
tering thoughtful and compassionate others. At the same time, it functioned as a reminder of the openness required for making possible relationships through writing, and so ultimately, the risk and the vulnerability of being human.

\section{Interweavings: From Collective to Collaboration}

Assuming that learning is "a fundamentally social phenomenon, reflecting our own deeply social nature as human beings capable of knowing" (Wenger, 1998 , p. 3), we encounter too often the loss of community that is prevalent in education today. Informed by perspectives in writing process theory (Cooper, 1986; Lensmire, 1994; Park, 2005) and communities of practice (Lave \& Wenger, 1991) through which we understand that the act of writing creates worlds and is a way of coming to know differently, we collaboratively engaged in and contributed to the construction and interpretation of our writing, our learning, and ourselves. Ours was not a therapeutic community. Rather, we were a community of inquiry that was captivated by questions of ontology, epistemology, and pedagogy as they apply to our lives and work as women writing (Palmer, 1993). Writing in the creative space of the collective allowed and encouraged the negotiation of our individual and collective identities as creative women academics, writers, and thinkers. Through reading or sharing our works-in-progress, we took turns receiving responses from others in the group. Often, these responses included critical feedback, relational connections, spontaneous emotional responses, connections branching off into new connections, and sometimes, even silence.

We also wrote in each other's presence. We regularly engaged in what Natalie Goldberg (1986) described as wild writing, a timed freewrite that is written individually on a collectively chosen theme, topic, or word. Such writing supported our learning, and it encouraged a sharing of writing that was immediate and created within each other's presence.

Written artifacts of events within the collective are traces of past discussions, juxtapositions, scaffolding of ideas, thoughts, feelings, a relational aesthetic (Gablik, 1991) that we use to explore various issues in the academy about not only academic loneliness, desire, competitiveness, and isolation, but also collectivity, creativity, collegiality, personal development, and scholarly endeavor. Through this process, we supported each other as our writing progressed, whether it was scholarly or personal, individual or communal.

We often shared our freewrites by reading them aloud and collectively engaging in a discussion of how the writing moved us, informed us, kindled forgotten memories, unleashed hidden feelings, evoked new ideas, challenged

NJAWHE 2014, 7(1)

(C) NASPA 2014

http://journals.naspa.org/njawhe

doi:10.1515/njawhe-2014-0002 
perspectives, and made visible that which might have remained forbidden and invisible in our academic lives. Often similarities of metaphors, images, or feelings would emerge, which when reflected upon, called our attention to our common concerns.

While the immediate act of writing was individual, it was remarkable how often the respective pieces revealed and echoed our individually accessed thoughts within the collective. During one of our gatherings for example, one member spoke of the paradox of institutional valuing of first authorship in an emerging environment where one's desire for and practice of academic research is increasingly collaborative. The concerns and the expressions of disempowerment that we spoke about found expression during the 5-minute freewrite that followed our conversation:

Underneath the apple tree ${ }^{1}$

we gather, a momentary pause,

a baby welcomed, a writer lost

a bruising, this too is our

welcoming, a hand out to rescue

to hold, to still the sadness

of an institution that demands first author. *

(Lynn)

listening to women

speak of writing

challenges, tricks, schedules

How to navigate the intensity of

the process of writing

We are mature women writing

Yes, writing and putting our words into the world

First authors, multiple authors, last authors, connected authors

writing *

(Barbara)

${ }^{1}$ Our inaugural meeting began under the apple tree in one of our member's backyards. On the day of this freewrite, we welcomed a new member, told her our history, and when we invited her to name our topic for our freewrite, she proposed, "under the apple tree." 


\section{Learning Wisdom Through Collectivity}

in your words i hear:

the poem,

the story,

the essay,

the art-icle,

the book,

in your words i hear:

you

coming to life,

i hear you

coming to life through and into

words,

we

create each other daily with this writing,

we

create each other daily reading and speaking this writing,

we

create each other daily

with these filaments of letters strung across the page,

i would string for you the word,

i would string for you the sentence,

i would string for you the chorus of both,

and meet the longing of filaments

of letters,

strung across the page

words touch

and hold,

hold all this,

hold all this reaching of your

filaments of

letters strung across the page. *

(Nané) 
As The Women Writing Women Collective, we explored language, thoughts and theoretical perspectives, forms of scholarly dialogue, and engagement. We agreed with Gablik (1991) that, "There is a need for new forms emphasizing our essential interconnectedness rather than our separateness, forms evoking the feeling of belonging to a larger whole than expressing the isolated, alienated self" (p. 5). Gablik's notion of radical relatedness helped us to shift from 'individual isolation' to 'collective collaboration,' and from academic writing to wild writing as a means to enter deeply into our scholarship. We needed to interrupt, disrupt our habits of scholarly engagement, in order to come to renewed understanding of our work. Educator Elizabeth Lang noted in her study of adults going through life transitions that an understanding and experience of radical relatedness is crucial to recovering "suppressed values/ ethics and forgotten relations" (2004, p. 135) that can then lead to "restorative learning" (p. 137). She proposes that restorative learning is a necessary bridge to transformative learning and new ways of being in the world. The dialectic between restorative and transformative learning affirms that transformation is in relation to one's place in the world, not just epistemological in its nature, but ontological.

Our experiences as writers, educators, and researchers were relationally weighed and sifted, as we made choices regarding that which is named as important or perceived as trivial, what is personal or public, what to include and what to exclude. The result was an intricately interwoven, overlapping, juxtaposed, creative resonance, a collective emergence of recorded 'neighboring interactions' (Davis, Sumara, \& Simmt, 2003) sounded out in each other's presence. Each of us brought to the Collective fragments of writing, writing frustrations, first drafts, and rewrites; and encouraged each other to explore new forms, new ways of engaging in scholarly writing. What began primarily as a practice in writing extended into informed and informal teaching, as we shared a diversity of theoretical lenses.

For example, at one meeting, Barbara read a first draft of what she called a curatorial statement, and she explained her need to locate herself in relationship to her work-not as an "anonymous I," or as an "academic I," but as an "I within a positionality." She understood her arts-based dissertation research as three separate art installations and felt that she could best speak to her work from the perspective of a curator. Her curatorial statement, thus, was also a proclamation of academic positioning and negotiation. After listening to her reading of her text, there was a collective pause, and then thoughtful critique, ranging from suggestions to realign phrases, to asking for the meaning of the word "apophatic": 


\section{Learning Wisdom Through Collectivity}

Wendy: I don't know what that word means.

Barbara: Apophatic. It's a theological term about coming to know through unknowing. It's where the path of the soul journeys through darkness to transformation, rather than through the light.

Gillian: Ah! Your explanation opens up what you are saying. I understand your text differently now.

Lynn: Barbara, by explaining what apophatic means, your theoretical writing becomes more complex and intriguing to the reader. You should footnote it.

Barbara: I'm not into footnotes. I'm even having problems contemplating the use of endnotes. I just want to let the writing flow.

Throughout the course of our time with the Women Writing Women Collective, our suggestions and writings were met with curiosity, questioning, resistance, openings in a theoretical and representational negotiation of what it means to render visible and knowable the as-yet-unknown. At times we were uncomfortable, resistant, persistent, silent; we encouraged each other to "mind the gap" (Taylor \& Saarinen, 1994), we called attention to what was absent, what was troubling, what moved us to tears.

Following Barbara's complaint about footnotes was a conversation about the pros and cons of footnotes, endnotes, the interruptions of APA style, the hours of writing a writer should commit to daily, and dealing with recalcitrant thesis committee members; and, more importantly, we shared our struggles to reclaim writing, to engage with it meaningfully, with care, within the spirit and tempo of our engagement, as well as sharing and expanding our relationships within theoretical positionalities.

Often, our conversations began with discussions of the practical, the pragmatics of writing, only to evolve and invite new understandings of ways of living poetically and with care within the academy (Leggo, 2004; Noddings, 1992). In one meeting, Alyson spoke to her frustration of not being able to write productively for eight hours. In response, Wendy shared with us her time schedule and engagement with writing: "I'm totally linear," she acknowledged; while Lynn spoke to "sneaking up" on the writing of her thesis by beginning with field notes (Meyer, 2006) that described what she saw outside her window, small writings that eventually were interwoven with the thesis research. These conversations are not limited to how each 'I', as an academic writer, was writing a doctoral thesis or academic paper, but rather were part of a much 
larger conversation of what it means to be engaged in a writer's life, of our commitment and struggle to give voice to who we are and what matters in our work.

During another meeting, Barbara shared with us a statement from Matthew Fox (1988): "No one goes to university today for wisdom . . . wisdom is no longer a category in education and university" (p. 22). University, Fox reminds us, "originally meant a place where one went to experience his or her place in the universe," it was not an academic assembly plant segmented into disconnected disciplines. Gillian then shared her research around issues confronting interdisciplinary studies, and spoke to the resistance that interdisciplinary students encounter as they seek to place themselves and their work within the university structure. While our conversations did not solve all the problems we experienced in our academic lives, we learned from each other, we listened, and we acknowledged what mattered to us collectively and individually.

These conversations served as mending places, reworkings of our academic experience, revalidations of the tasks we had undertaken. This was a practice of healing, of restoration, of transformation. Our experience of collectivity was an ongoing evolving process, whereby our past commitments were revisited and future directions were always emerging into relationality. Our inquiries were variously autobiographic, ethnographic, phenomenographic, performative, arts-based, and narrative. The appropriation of language, invention, asking questions, negotiating new meanings, and shaping of the self occurred in expressive (and often autobiographical) writing alongside emergent understanding of how we related with others. We wove our individual realities into the collective sensibility, placing and positioning the self as part of the coherent whole, not separate from it. We not only recorded what happens 'next,' but rather, we became the 'next,' as narratives became nested in a meaningful context of our collective making. We honed our craft, and we wrote (our) lives (Park, 2005) as we reimagined the scholarly life and practice of an academic writer.

We relied on awareness of representational modes rather than representation as fact or 'reality.' Our essence was to be in relation, rather than outside, and through relationality, reveal layers of connection between and among our varied experiences. We discovered that we co-belong within the openings we cocreate (Irigaray, 2002). As women in various stages of scholarly growth, we were in the ongoing process of negotiating our identities within and without the academy, and thus witnessing each other's becoming (Bakhtin, 1986; Britzman, 1991): "To experience this co-belonging implies leaving representa- 
tive thought and letting oneself go in the co-belonging to Being which already inhabits us, constitutes us, surrounds us" (Irigaray, 2002, p. 70).

\section{Learning as Belonging in Community}

Wisdom is our understanding of radical relatedness, our connection to the universe and each other. Theologian Mathew Fox (1988) and Medieval mystic Hidegard of Bingen (as cited in Fox, 1985) remind us that wisdom is often understood cross-culturally as a feminine figure and that it has been lost/ repressed within academic learning. A return to radical relatedness within the academy begins to surface these qualities of wisdom, a way of being that does not separate "rational and arational ways of knowing," (Bickel, 2008, p. 10) but embraces both. As a new generation of female scholars, we continually inquired: How can we turn and bring relational understanding to the academy? How do we nourish and protect that wisdom? Wisdom does not emerge through careerism, through the competitiveness that infiltrates academic undertakings, breeding a disconnected, fragmented, and unhealthy (i.e., pathological) environment. How do we speak to care, nurturing, and relationship within the academy? What language, recognitions, and acknowledgements are granted to individual and collaborative groups within the academy?

In one collective conversation, Barbara spoke about wisdom that draws from both right and left hemispheres of the brain (Fox, 1988), and Alyson then told us about her struggles to submerge herself within theoretical writings. She read from her latest writings (not academic, she said), about drowning. These writing interludes helped to support her as she worked through the heavy theoretical discourse of her dissertation writing and demonstrate the arational emerging within her rational reflection:

Memories ... remembering and forgetting. Lately, I've had the feeling that my memories occupy some kind of liminal space, where things are not quite remembered and yet not completely forgotten either. I am drowning in the present. The day-to-day monotony of carrying out the tasks necessary for living is getting me down, weighing heavily. I long to be hovering above in the atmosphere, having escaped with the freedom of my thoughts. I am learning to take better care of myself. . . . Tina says the thing I need to work on is broadening my sense of interiority, that the difficulty I'm having revolves around the absence of language for describing my feelings and aspects of inner experience. I wonder if I can begin to make a language from water...could the images which water presents me 
with—clarity, coolness, warmth, refreshment, weightlessness—-help mitigate the dread and fear I experience from this persistent feeling of drowning? I first need to catch my breath. Then I might speak.

Alyson's written interplay between the personal and the theoretical interconnected the vitality and wisdom of her lived experience: "These writings could be interspersed within your thesis," we told her, awed by her wisdom and insight. And then Lynn remembered and shared the experience of one former member who wrote and wrote and wrote, and then one Sunday morning at a gathering, plunked 300 pages of writing on the coffee table, and lamented, "I've done all this writing, but not a word on my thesis!" As the group looked at the pile of writings, someone ventured, "But this is your thesis."

There are times when we do not recognize that work we do is our academic work-a painful, personal, apophatic journey that leads the individual, the collective, and in turn, the institution to new understandings; it is a witnessing and confirmation of how we might engage anew within the academy. Through our conversations and writing together, we came to understand the potentiality of "coming to know through unknowing" as a journey of revelation for those academics who choose to engage co-relationally in a life of inquiry. To welcome our writing is a healing act, to recognize that this too is scholarship, illuminating a poet's wisdom: "There is a crack in everything/that's how the light gets in" (Cohen, 2002). What may seem an impenetrable fortress may be seen by others as a portal to renewed scholarship and passion.

There evolves a wisdom from sharing and being in the presence of each other's work over time. We learned that the simple act of reading aloud, without critique or comment - the listening that we as writers desire-requires a witnessing; the oral reading of text made present through sound, vocalized, and returned by listener, reverberating off bodies, creates a reciprocal reading that brings new insight to the writer. The body's response is enough sometimes, is all that is required, so that each reader may come to listen to her own work anew. This was a collective act of receiving and sharing, a witnessing that embodies companionship, receptivity, and welcome. Our responsibility was both to each other and the academy, to promote, to jostle, to interrupt, to disturb, and to propose that this too is possible.

As the collective moved forward, we began to explore the value of our commitment to the collective. At one meeting, as we sought to vocalize what matters about our collectivity as female writers and academics, we asked why we valued the Women Writing Women Collective. We did a freewrite on the particular meaning or relevance to us as members of the collective. We gath- 
ered the words and share them below as an example of our emergent understanding of coming to renewal and well-being through the collective:

artists, educators, writers, scholars

diversity of engagements

diversity of identities

thoughts are named, given value

transformative

nurturing and sustaining

challenging socialization/socialized patterns

interflexion

holding the trust

commitment

respect

kindness "mindfulness is better"

criticism

generosity

sharing

we meet in each other's homes

we want to hear each other's writing (an unusual space)

nurturing space

trust that words will take us somewhere we didn't know we would go

we are women who have something to say in the world

"we encourage each other to actually say it"

invitation/permission

audience is relationship/connection to each other

audience to our process of writing

witness to our presence/inquiry

relationship is desired, writing creates it?

We explored and elaborated these thoughts, trusting in each other's wisdom and mindfulness to renew our commitment to the collective, as well as our endeavor to seek wisdom and well-being within the academy.

Another freewrite towards the end of our 5 years together began the process of revisioning and opening the group to new members in an effort to continue to imagine ourselves within the context of the collective, and wondering how we could support the collective to continue to thrive. Curiously, we each described our understandings of the collective by way of invitation to others.

NJAWHE 2014, 7(1)

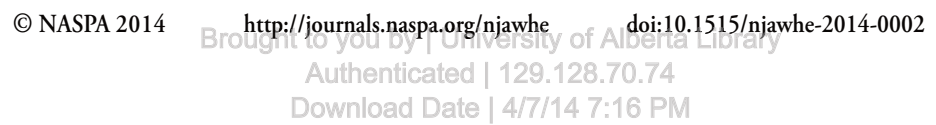


Nané called our attention to the radical relatedness of our collective as "a community of women going forth in/to and of the world, creating, re-creating 'the self,' [seeking] balance of 'ego,' calling for individual reflectivity of group processes.” Jeannie wrote:

The group exists to help each woman to discover and recover the writer within, encouraging each other to continue to move forward, believing and acknowledging that her voice is of value in the teaching of all women as they "wander through the dark woods or their destinies" with the conviction that they are educators (D.H. Lawrence).

Barbara noted, we are "women who have something to say within the world" and our collectivity is the vehicle for our voices. Wendy added:

Through this space, we explore personal and collective identity, belonging to the various communities of which we are a part . . celebrate each other's achievements, challenges, and inner-workings. Our promise to each other is that we will be open, generous, critical, helpful, and kind.

In evoking community, we drew a fine line between and among negotiation of boundaries, relationships, and responsibilities, learning to hold and behold each other and our work. This attention to our responsibilities to each other reflects a generative tension of interplay between personal and professional, intimacy and scholarship.

Our collective travels were not without their perils. Decision-making and collective engagement were reflexive and iterative processes that needed time for interweaving personal and social aspects among the writerly and scholarly ambitions for those of us in the academy. Through this work, we learned we needed to be individually open to the collective in ways that "complicate definition and give room for the possibility of creatively mated taxonomies and their wildly unpredictable offspring" (Patricia Williams, in Ellsworth, 2005, p. 147). The simple and seemingly isolated act of personal or academic writing is a complex social reality (Park, 2005), and through our 5 years of conforming, unforming, reforming, and transforming within this collective, our understandings continued to evolve. Our experience as a collective opened a much-needed dialogue on the complexity of transformational learning communities (Mezirow, 2000; O’Sullivan, 1999), particularly within academia. We were challenged to learn how to keep dialogue open, even during painful occurrences, and to remain open to new decisions on how to move forward together, how to continue to care for one another, how to work collectively 
and collaboratively even in absence; how to forefront the valuing of our work; how to live with loss, with reverence and irreverence, with humor; and how to continue to grow and learn together. We were no longer isolated, but rather a part of a critical co-mentoring, nurturing social network that supported restorative and transformative learning experiences.

\section{Opening Collective Learning to Others}

We found that public presentation of our experiences invites a wider collectivity, creating a rich opportunity and space for response to particular words, particular ways of being in communion with each other. Something new happens within public spaces of sharing: we make connections, receive and are challenged to make meaning in the presence of others-strangers and those known to us. At one conference, for example, we invited the audience to freewrite with us on the theme of "Evoking Desire . . and Irreverence." One member of our audience, who is now a member of our collective, wrote:

Irreverence, irrelevance. What does desire have to do with science and engineering education? Where is desire in my life? How do we evoke it? Call it forth? Reflect on it? Build on it? ... Afraid of it. Do I want to evoke it? As a teacher, do I want to be desired, desirous, desiring? What will I unleash? What will I give up? Desire. Desire to be, desire to write, desire to find desire.

Moving forward, we want to further explore key questions that emerged:

- How can we offer critical feedback to each other, while nurturing the relationship within the group and well-being of the collective itself?

- How do we navigate the tensions and unmarked borders that arise in the interplay between the personal and intimate, the scholarly and professional?

- How do we take the learning, the wisdom that has evolved through our work together, and through our engagements within the academy, begin a rewriting of our lives within the academy that is respectful, caring, and cognizant of the reciprocity that is the relationship between who we are as academics in relationship with each other?

These are important questions in the life of our learning community, and, on a wider scale, for female academics in general who are seeking a way to nourish scholarly and sustainable academic careers.

NJAWHE 2014, 7(1)

(c) NASPA 2014

http://journals.naspa.org/njawhe

Authenticated | 129.128.70.74

Download Date | 4/7/14 7:16 PM 
We offer here a preliminary answer: When sharing written work with the group, we asked that members take the responsibility to indicate the kind of response they were seeking. Giving critical feedback is vital for individuals so that they continue to develop as writers and scholars, and we learned from each other how to give constructive feedback in an honoring, caring, and respectful way. Similarly, we sought to articulate the borders of our intimate and scholarly lives. Recognizing that such borders are porous and intertwined, we learned that it was important to focus our conversations around our writing and the challenges we faced as scholars living in relationship with others. Personal crises, we learned, are best addressed outside group meetings. While we have come to recognize the therapeutic empowerment that comes from sharing scholarly challenges as they impact our personal lives, we also learned not to direct our energies towards trying to solve problems of individual group members during our time together. Such caring emerges through the group for each other, but was best practiced outside of our writing and meeting times.

By opening our own explorations as a writing collective to sharing with a wider public, we have come to understand that the personal and public are intimately interwoven. We now recognize the richness of the tensions that arise in the struggle to create a scholarly writing practice that acknowledges the relational. Working toward the balance was itself a transformational experience as we constantly negotiated our own relational spaces within the collective. As we continue in our journey to reimagine academic possibilities of engagement, to bring into being a radical relatedness that challenges and shifts our academic practices and relationships, we expressly invite others to build their own writing collectives as spaces for collegial, yet highly personal learning and exploration. Our experience through writing with the collective, our conversations, and our constant shifting, illustrates a possible way that scholars may learn and engage in healthy ways of renegotiating their presence within the academy, thus creating places and spaces of well-being. As Maxine Greene (1978) reminds us, we must be in a state of "wide-awakeness" to the discomforts and diseases that are too often our experience in the academy, and to take mindful action. Given the rich learning of our experience, we encourage others to create their own writing collectives as a form of joyful revolt against isolating hegemonies (Kristeva, 2002), and to explore collectively emergent possibilities, opening spaces for dialogue through writing together. 


\section{References}

Asmar, C. (1999). Scholarship, experience, or both? A developer's approach to cross-cultural teaching. International Journal of Academic Development, 4(1), 18-27.

Bakhtin, M. (1986). The dialogic imagination (C. Emerson \& M. Holquist, Trans.). Austin, TX: University of Texas.

Bickel, B. (2008). Writing the body/resistance/endurance: An a/r/tographic ritual inquiry. Educational Insights, 12(2).

Britzman, D. (1991). Practice makes practice: A critical study of learning to teach. New York, NY: State University of New York.

Britzman, D. (2003). After-education: Anna Freud, Melanie Klein, and psychoanalytic histories of learning. Albany, NY: State University of New York.

Britzman, D. (2006). Novel education: Psychoanalytic studies of learning and not learning. New York, NY: Peter Lang.

Cohen, L. (2002). Anthem. The essential Leonard Cohen [CD]. Canada: Sony BMG Music.

Cooper, M. M. (1986). The ecology of writing. College English, 48, 364-375.

Davis, B., Sumara, D., \& Simmt, E. (2003, October 16-18). Complexity and collectivity: On the emergence of a few ideas. Proceedings of the $2003 \mathrm{Com}$ plexity Science and Educational Research Conference. Edmonton, Alberta: University of Alberta.

Dunlop, R. (2002). Who will be the throat of these hours . . if not I, if not you? Educational Insights, 7(2), 12.

Ellsworth, E. (2005). Places of learning. New York, NY: Routledge Falmer.

Eugenides, J. (2002). Middlesex. New York, NY: Picador.

Fox, M. (1985). Illuminations of Hildegard of Bingen. Santa Fe, NM: Bear \& Company.

Fox, M. (1988). The coming of the cosmic Christ. San Francisco, CA: Harper \& Row.

Gablik, S. (1991). Reenchantment of art. New York, NY: Thames and Hudson. Goldberg, N. (1986). Writing down the bones. Boston, MA: Shambhala.

Greene, M. (1978). Landscapes of learning. New York, NY: Teachers College. Irigaray, L. (2002). The way of love. London, England: Continuum.

Kristeva, J. (2002). Stabat Mater. In M. Joy, K. O’Grady, \& J. L. Poxon (Eds.), French feminists on religion: A reader (pp. 114-138). London, England: Routledge.

Lang, E. (2004). Transformative and restorative learning: A vital dialectic for sustainable societies. Adult Education Quarterly, (54)2, 121-139.

NJAWHE 2014, 7(1)

(C) NASPA 2014

http://journals.naspa.org/njawhe

doi:10.1515/njawhe-2014-0002 
Lave, J., \& Wenger, E. (1991). Situated learning: Legitimate peripheral participation. New York, NY: Cambridge University.

Leggo, C. (2004). The curriculum of joy: Six poetic ruminations. Journal of the Canadian Association for Curriculum Studies, 2(2), 27-42.

Lensmire, T. (1994). Writing workshop as carnival: Reflections on an alternative learning environment. Harvard Educational Review, 64, 371-391.

Meyer, K. (2006). Living inquiry - A gateless gate and a beach. In W. Ashton \& D. Denton (Eds), Spirituality, ethnography, and teaching: Stories from within (pp. 156-166). New York, NY: Peter Lang.

Mezirow, J. (2000). Learning as transformation: Critical perspective in a theory in progress. San Francisco, CA: Jossey-Bass.

Noddings, N. (1992). The challenge to care in schools: An alternative approach to education. New York, NY: Teachers College.

O'Sullivan, E. (1999). Transformative learning: Educational vision for the 21st century. Toronto, ON: OISE/UT and University of Toronto.

Palmer, P. (1993). To know as we are known: Education as a spiritual journey. San Francisco, CA: Harper Collins.

Park, J. (2005). Writing at the edge: Narrative and writing process theory. New York, NY: Peter Lang.

Reynolds, A. (1992). Charting the changes in junior faculty: Relationships among socialization, acculturation, and gender. The Journal of Higher Education, (63)6, 637-652.

Taylor, M., \& Saarinen, E. (1994). Imagologies: Media philosophy. London, England: Routledge.

Wenger, E. (1998). Communities of practice. London, England: Cambridge University. 